\title{
Ethnography in Early Childhood Education a
}

Jenny Ritchie

Subject: Research and Assessment Methods Online Publication Date: Jul 2019

DOI: $10.1093 /$ acrefore/9780190264093.013.532

\section{Summary and Keywords}

Ethnography is a qualitative methodology worthy of consideration for application in studies within the field of early childhood education. The long-term, immersive, relational nature of ethnography enables rich, detailed descriptions of the complex interactions occurring, and ongoing engagement with children, families, and teachers provides the opportunity for co-analysis of the meanings that underlie the observed activities and interrelationships. The foremost source of data for ethnographic research is the regular writing of in-depth fieldnotes over a lengthy period of time, which may be supplemented by photographs, videos, interviews, focus group discussions, and analysis of relevant documents. Issues to be considered by those intending to conduct ethnographic research in early childhood care and education settings include: their availability to be immersed in the site that is the focus of the study, on a regular basis over a long period of time; sensitivity to power dynamics between adults and children and to cultural differences; the ethical issues pertaining to gaining and maintain young children's informed consent; and collaborating with participants, including young children, in co-analyzing the meanings underlying the data gathered. The ethnographic researcher in an early childhood care and education setting can attend to such issues through an ongoing receptivity to the messages, including body language, of participants, along with a commitment to self-reflexivity on an ongoing basis. The nuanced, culturally located understandings that are gleaned by ethnographic researchers offer potential for such research to inform policymakers in relation to delivering conditions that will enable teachers to offer high-quality, culturally responsive early childhood care and education pedagogies and programs.

Keywords: ethnography, early childhood education, preschool education, childhood studies, cultural studies

\section{Introduction}

Ethnography is a qualitative research methodology particularly suited to research projects that aim to gain in-depth understandings of the lived experience of children and teachers in early childhood care and education settings. It offers researchers the opportunity to discover in an emergent, responsive way the intricate dynamics of interactions and motivations of the members of this setting via long-term engagement with participants on a regular daily basis. Philosophically, ethnography in early childhood settings aligns with 
the philosophical and pedagogical approaches of early childhood educators who uphold professional codes and expectations that involve building relationships founded in a deep respect for children and their families, their cultural values, and their aspirations.

Ethnography also enables the investigation of microcosms of interrelationships and interactions that reflect wider historical, social, economic, political, and cultural influences and issues of the wider society.

\section{Defining Ethnography}

Ethnography is a qualitative research methodology most often associated with the field of anthropology from which it emerged. It serves to provide rich, in-depth understandings of the cultural beliefs and lived practices of particular groups of people. Cultural anthropologist Clifford Geertz has explained that the term "ethnography" is used to refer to "both a process and a product of the study of human culture" (1973, as cited in Lubeck, 1985, p. 47). The educational ethnographer Harry Wolcott described doing ethnography as "a way of looking and a way of seeing" (Wolcott, 2008, p. 41), the ethnographer producing a "picture of the way of life of some interacting human group" (Wolcott, 1975, as cited in Lubeck, 1985, p. 47). A distinctive aspect of ethnography is the need to conduct fieldwork over a long period, typically a year at minimum, spending time in the community that is the focus of the study, "sharing their work, thoughts, and concerns" (Lubeck, 1985, p. 49). The renowned cultural anthropologist Margaret Mead describes the ethnographer as being willing to learn the language of the community being researched, and being immersed in their ways of being, in order to "get their culture sufficiently by heart to feel their repugnances and sympathise with their triumphs" ([1930] 1968, p. 213, as cited in James, 2011, p. 5).

The aim of ethnographic study is thus "to provide holistic accounts that include the views and perspectives, beliefs and values of all those involved on the particular sociocultural practice or institutional context" of the research focus (Siraj-Blatchford \& Siraj-Blatchford, 2001, p.193). Ethnography relies "fundamentally on first-hand, personal involvement in the lives of people being studied" (Eisenhart, 2001, p. 18). "Ethnographic research typically involves prolonged fieldwork in which the researcher gains access to a social group and carries out intensive observation in natural settings for a period of months or years" (Eder \& Corsaro, 1999, p. 523). Geertz defined ethnographic work as being an interpretative act of "thick description" (1973, pp. 9-10, as cited in James, 2011, p. 3). The researcher, through close involvement in the community and with participation of community members, attempts to portray the understandings through the lens of the community members, generating a "holistic description" (Eisenhart, 2001, p. 23). The methodology acknowledges the interpretative role of the researcher(s). However, an important distinction is that this "mode of interpretation goes beyond the microscopic examination of action and to their contextualisation in a more holistic sense, to capture successfully actions and events as they were understood by the actors themselves" (Eder \& Corsaro, 1999, p. 523). 


\section{Background to Ethnography in Early Childhood Education}

Anthropologists interested in the processes involved in the socialization of children into the adult culture provided the precursor to later ethnographic work focused on early childhood care and education settings. These early influences included the American scholar Margaret Mead, whose studies included Coming of Age in Samoa (Mead, 1928) and Growing Up in New Guinea (Mead, 1942). Mead's depictions of societies that functioned with widely varying cultural patterns challenged Western assumptions in relation to normative practices of childrearing, heteronormativity, and patriarchy. In her wideranging ethnographic studies Mead chronicled the "extraordinary variations in systems of rearing and educating children" (Lubeck, 1985, p. 18). From the work of Mead and others, including her colleague Ruth Benedict (1983), there emerged a growing recognition that anthropology could provide insights not only into the lives of people in non-Western cultures but also into the worlds of people, including women and children, whose voices have historically often been muted (Hardman, 1973/2001).

As the methodology of ethnography was taken up by disciplines beyond anthropology, including sociology, psychology, cultural studies, human geography, and education (Konstantoni \& Kustatscher, 2016), a growing range of applications and insights emerged out of the influences and applications of these various disciplines. Attention to considerations emerging from postmodernist work in such disciplines as philosophy, feminism, literary criticism, ethnic studies, cultural studies, and post-colonial critique have reinforced the need for sensitivities with regard to being definitive. This is seen, for example, in the questioning of claims of cultures depicted as "clearly bounded and determined, internally coherent, and uniformly meaningful" (Eisenhart, 2001, p. 17). These theoretical perspectives are reflected in the work of critical ethnographers of education (Kincheloe, McLaren, \& Steinberg, 2012). Following the trajectory of critical theory, critical ethnography visibilizes hegemonic power dynamics between different groups of people and the cumulative effects of multiple oppressions on both ethnographer and participants (Erickson, 2011).

\section{Ethnography in Early Childhood Education}

The social upheavals of the 1960s in relation to civil rights for African Americans, the women's liberation movement, and the anti-war protest movement provide the backdrop to the social justice lens that is evident in educational ethnography (Lubeck, 1985). Within this broader context of sociocultural, equity, and social justice awareness along with critical analysis of societies, ethnography came to be utilized by researchers interested in early childhood education, such as Valerie Polakow (Suransky) (1982), Sally Lubeck (1985), William Corsaro (1985, 1996, 2003), and Joseph Tobin and his research colleagues (Tobin, 2016; Tobin, Arzubiaga, \& Adair, 2013; Tobin, Hsueh, \& Karasawa, 2009; Tobin, $\mathrm{Wu}, \&$ Davidson, 1989). Researchers such as these have endeavored to understand not 
just the intricate occurrences observed on a day-to-day basis within the early childhood care and education center but also the wider cultural patterns observed in participants' ways of being, knowing, doing, and relating that are resonant of the historic, economic, and political contexts that inform societies. The remainder of this section briefly outlines several of these influential early childhood ethnographies.

Valerie Polakow (1982) located her ethnographic study in a historical context with views of childhood ranging from the medieval period to contemporary Western economies that separate children from the world of work, "having infantilized their perceptions and moral sensibilities with insidious moral inventories and taxonomies, where there experiences, intellect, and state of being are constantly measured, quantified, and evaluated" (Polakow Suransky, 1982, p. 27). She highlights the positioning of the ethnographer of childhood, in that "Becoming an anthropologist of a culture once inhabited, yet now transcended, involves a dialectical reconciliation with one's own historicity" (Polakow Suransky, 1982, p. 29). For Polakow:

We, in the process, become anthropologists of childhood, investigating the phenomenology of that life project in order to derive insight into the meaning structures of that life-world and to be transformed by our understanding of the experience; for understanding the child from the perspective of his world is to hold the view that, despite biographical and developmental determinants, the growing child is an intentional actor constructing a life project with consciousness, that becoming in the world involves a dynamic self-representation, that the child too, is a historical being, a maker of history, a meaning-maker involved in a praxis upon the world.

(Polakow Suransky, 1982, pp. 35-36)

Polakow's two-year study aimed to provide a "finely etched, composite portrait of a modern institutional childhood" (1982, p. 54) as observed in five contrasting early childhood care and education settings in the American Midwest. These comprised a Jewish preschool, a for-profit urban center, a Montessori program, an African American community center, and a Summer Hill inspired "free school," with a "free play" philosophy in which she described the children as being "free to create their own landscape" (Polakow Suransky, 1982, p. 160, emphasis in original). Polakow concludes that "play, as the child's praxis upon the world, should not be dichotomized from work: for the playing child is a working child-engaged in meaningful, purposive activity" (p. 172). In this manner, the "child becomes herself through play" (Polakow Suransky, 1982, p. 172, emphasis in original). Polakow also presciently signaled the harm caused to young children attending corporate profit-oriented "childcare" settings, which treat the child purely as a source of profit and reduce the numbers of staff, stating that:

It is under those conditions that a profit turnover can be increased and it is these very conditions which produce fragmentation, hostility, violence and severe forms 
of alienation, contributing to the overwhelming experience of anomie within the life-world of the child.

(Polakow Suransky, 1982, p. 187)

Sally Lubeck's (1985) comparative study of a middle-class preschool and a working-class Head Start early childhood care and education center arose from her interest in ways in which young children were socialized by adults in various settings. She inquired:

What do adults perceive as their situation in life? How are values and attitudes transmitted to children? How do adults structure their immediate environment? And what subsequent behaviors are observable in the children? In brief, what do adults $d o$ to orient children to adapt to the world in a particular way?

(Lubeck, 1985, p. 41, emphasis in original)

Her year-long study identified distinctive contrasts between the personnel and pedagogical approaches in the two centers. She found that the white middle-class preschool teachers generated a program that replicated the individualistic values and practices of white nuclear families, whilst the African American Head Start teachers worked collectively to promote values of collectivism via routines and collaboration within group activities.

Also coming from a social justice perspective, the work of Australian scholar Glenda Mac Naughton has shed light on ways in which young children demonstrated and perpetuated gender power and racism in an early childhood setting (Mac Naughton, 1993). For Mac Naughton:

The day-to-day world of the classroom provides a rich source of information about how children's relationships develop and change over time. The complex ways in which young children produce and reproduce racism through and in their play are likely to missed by research that is not situated within a "real-life" context, such as the early years classroom.

(Mac Naughton, 1993, p. 15)

A key focus in the work of the sociologist William Corsaro's studies in both the United States and Italy was children's friendships and cultural groupings as defined, organized, and negotiated by children within the early childhood setting (Corsaro, 1985, 1996, 2003). One example of this child-negotiated practice is the tendency of children to resist attempts by other children to enter their play (Eder \& Corsaro, 1999). A cursory view from an adult perspective might judge such resistance as being exclusionary and unfair. However, through his ethnographic work Corsaro came to understand this behavior as "protection of interactive space" whereby children were motivated to continue with play that would otherwise be disrupted by the entry of children who didn't share prior understandings around participation in the pre-negotiated format (Eder \& Corsaro, 1999, p. 524). Corsaro thus shifted the lens of his study focus from the broad view of children's 


\section{Ethnography in Early Childhood Education}

'peer interaction', to the more nuanced recognition of their "creative production of and participation in a shared peer culture” (Eder \& Corsaro, 1999, p. 524).

The work of Joseph Tobin and his colleagues utilizes an innovative approach which differs from the traditional ethnographic expectation of long-term immersion of the researcher in the study setting. Tobin and colleagues have applied their "video-cued multivocal ethnographic" method across a series of studies which compared early childhood education practices in different countries (Tobin, 2016; Tobin et al., 1989, 2009, 2013). This method involves a week of videoing within the early childhood setting, from which a 20-minute video is produced via selective editing. This is shown first to the teacher whose classroom was filmed, then to other teachers in the preschool, followed by wider viewing by teachers from that same country before finally showing the different country videos to teachers from the various participating countries (Tobin et al., 2009). The videos are not considered to be the key source of data but are employed as a tool to simulate discussion based on the activities or events depicted in the videos. This discussion is recorded, providing insights into the different countries' teachers' contrasting understandings of their own and others' pedagogies, of the children's behaviors, and of the values that underpin both of these. An innovative benefit of this method was that the surprise at another culture's very different early childhood practices can result in "spontaneous explication of indigenous assumptions concerning children that had eluded conventional ethnographic interviewing" (LeVine, 2007, p. 256). The longitudinal nature of the preschool in three countries studies has provided further insights drawn from the deep familiarity and unique intersubjectivities developed over years of co-constructing understandings across cultural divides (Hayashi \& Tobin, 2015; Tobin \& Hayashi, 2017). Collaborations between ethnographers of early childhood education from different countries and theoretical perspectives can enable wider interpretative lenses resulting in more multifaceted understandings as demonstrated in the work of Fernie, Davies, Kantor, and McMurray (1993).

In preparing a policy brief demonstrating the value of ethnographic research in relation to developing federal early childhood education policy in the United States, Jennifer Adair (2011) identified a number of critical areas where ethnographic findings provide a "contextual and culturally dynamic representation of how early childhood settings, families, teachers, children are trying to address challenges in U.S. early childhood education on a daily basis" (p. 426). These include the recognition of wide variability in children's identities, relationships and understandings across different contexts; the sense of disconnection felt by parents, caregivers and teachers from the policies that guided the early childhood programs and the lack of communication and collaboration between teachers and parents; that early learning is most effective when pedagogies build on children's cultural backgrounds and understandings; the variability of programs and policies in terms of outcomes, depending on different contexts; and the value of learning from overseas models of early childhood programs, pedagogies, and practices.

The possibilities for rich understandings to be derived from the microcosms represented in particular ethnographic studies in early childhood are exemplified in such diverse work as that of Rossholt on the embodiment of infants and toddlers in Norwegian early child-

Page 6 of 19

PRINTED FROM the OXFORD RESEARCH ENCYCLOPEDIA, EDUCATION (oxfordre.com/education). (c) Oxford University Press USA, 2019. All Rights Reserved. Personal use only; commercial use is strictly prohibited (for details see Privacy Policy and Legal Notice). 
hood settings (Rossholt, 2009); considerations of the possibilities of interspecies learning in centers in Australia and Canada (Taylor \& Pacini-Ketchabaw, 2015); and children's perspectives via the application of "critical sociological empathy" in a study in a Danish day care institution (Warming, 2011).

\section{Why Ethnography Is Particularly Suited to Re- search in the Field of Early Childhood Educa- tion}

Ethnography has in recent years come to be widely recognized as a useful methodology for educational research, influenced in part by "the new sociology of childhood" (Corsaro, 2015) and by the promotion of children's rights discourses which position children as actively agentic in their lives. It is clear that in order for educators and education policymakers to be well informed in their work, ethnography can serve to provide a well-informed basis for decision-making:

To interpret what those participants under study are doing and saying, the ethnographer needs to know what daily life is like for them-the physical and institutional setting in which they live, the daily routine of activities, the beliefs that guide their actions, and the linguistic and other semiotic systems that mediate all these contexts and activities.

(Eder \& Corsaro, 1999, p. 521)

From an early childhood care and education perspective, ethnographic research shifts the lens from a positivistic approach of determining and measuring what children are learning, to trying to gain understandings of how they are learning (James, 2011) and how they are feeling, to processes rather than content, seeing children as informed, competent, engaged, and confident social actors who "collectively produce peer cultures" and also contribute to their wider culture(s) and societies (Corsaro, 2015, p. 84). Ethnography has come to be recognized for its potential to "engage with children's own views and enables their views and ideas to be rendered accessible" (James, 2011, p. 3). In this vein, ethnographers view children "as competent informants about and interpreters of their own lives and of the lives of others," and thus ethnography "is an approach to childhood research which can employ children's own accounts centrally within the analysis" (James, 2011, p. 10), as the "experts in their own worlds" (Tickle, 2017, p. 66). As such ethnographic studies can produce "a view of children as competent interpreters" of their social worlds (James, 2011, p. 2), and it is these rich understandings of children's "meaningful cultural worlds" (Ortner, 1991, p. 187, as cited in Eisenhart, 2001, p. 20) that when viewed from a social justice perspective and critical analysis by educators and education policymakers can lead to educational and political change. 
Ethnographic research is sustained and highly engaged over time. "By carefully entering the worlds of children and youth and charting the historicity of significant aspects and phases of their lives, ethnographers can document crucial changes and transitions that are essential for understanding socialization as a process of production and reproduction" (Eder \& Corsaro, 1999, p. 522). Children arriving into early childhood settings, increasingly at a very early age, are moving daily back and forth between the world of the early childhood setting and home, often spending more waking hours in the early childhood care and education setting than they do with their families. This "bimondial" transitioning on a daily basis means children may be in regular transition between very different sets of routines, values, and expectations (Zimmer, 1979). Sensitive understanding by early childhood care and education practitioners, informed by in-depth ethnographical research, has the potential to foster deeper reciprocal relationships between educators and their families and thus enhance the well-being of the young children who are the shared concern.

The "richness of ethnographic data" can also inform the theory and practice of early childhood care and education (Eder \& Corsaro, 1999, p. 524). The rich, detailed, and nuanced pictures of children's worlds enables a reconceptualization of the previous normalizing, universalizing nature of social science theorizing. Furthermore, privileging the voices and perspectives of young children challenges the adultism that has often excluded young children from having influence in decision-making that affects their well-being and happiness. According to Allison James:

Ethnography, then, has been critical to the development of a perspective on childhood which, in acknowledging its culturally constructed character, enables a view of children as social actors who take an active part in shaping the form that their own childhoods take.

(James, 2011, p. 7)

Ethnographic research has thus "unmuted" children's voices and positioned them as recognized social actors, enabling their views to be prioritized in decisions affecting them (James, 2011).

\section{Methods of Ethnography in Early Childhood Education}

Ethnography has a distinct history, characteristics, and terminologies, which include, for example, the long-term relational basis of both data collection and analysis and the use of extensive fieldnotes. It should not be viewed as a loose "catch-all" term for any form of qualitative research with groups of people (Aubrey, David, Godfrey, \& Thompson, 2000, p. 112). After obtaining the requisite ethical approvals, and prior to the lengthy period of data gathering, it is imperative that the researcher(s) take time to build relationships with and gain informed consent from all participants, including of course, the children (Tickle, 


\section{Ethnography in Early Childhood Education}

2017). Another distinctive feature of ethnographic research is the involvement of participants in a reciprocal relationship with the researcher(s) in both data gathering, interpretation and analysis. Researcher humility and integrity is key to this enquiry, in positioning the researcher(s) as open to learning from young children: "Instead of regarding young children as devoid of previous learning and experience, ethnography assumes them to have amassed a wealth of previous learning and experience-in short, a huge amount of knowledge" (Aubrey et al., 2000, p. 115).

Key to credible ethnography is the immersion of the researcher(s) in the research site over an extended period of time, during which extensive fieldnotes are recorded and analyzed on a daily basis. Richly descriptive fieldnotes are key to providing the contextual information, or "thick data" which inform the wider project and enable the refining of datacollection methods, accumulating over time to serve as the basis of the "thick description" of the study (Geertz, 1973, as cited in Aubrey et al., 2000, p. 116, emphasis in original). In addition to fieldnotes, "Standard ethnographic methods include participant observation, face-to-face interviewing, researcher reflection/journaling, and analysis of archival records" (Eisenhart, 2001, p. 18). Less intensive data-collection methods are sometimes described as being "informed by" ethnographic approaches. However, ethnography in early childhood is also an evolving methodology and over the years various researchers have incorporated video and photographs, collections of children's art and narratives, pedagogical documentation, records of group discussions, interviews with parents and teachers, and responses emanating from the use of the "photovoice" technique where children take photos and then explain the significance of these (Tickle, 2017). The effective application of all of these methods are dependent on building rapport within the community of the research setting, including center management, teachers, children, and families.

The ethnographic researcher in an early childhood setting takes on the often complex role of being a "participant observer." For Sally Lubeck (1985) this involved spending a great deal more time than she had anticipated in the working-class African American early childhood center, helping with cleaning and some of the duties of the teachers, in order to build trust and rapport. William Corsaro became "Big Bill," the large somewhat cumbersome playmate of the children whom he was researching (Coffey, 1999, p. 74; Corsaro, 2003). Valerie Polakow (1982) found her carefully planned individual interview schedule subverted by the staff of an African American early childhood center who decided to instead meet with her as a collective. A particular challenge for ethnography in early childhood education is the expectation that children be involved both in decision-making regarding the research process and in interpreting and analyzing data, particularly with regard to pre-verbal children, for whom siblings, parents, and teachers can serve as proxy. In many cases, the children may not have been consulted prior to the permission having been given by the center management and teachers for the research to begin.

However, during the fieldwork, children are able to participate in terms of negotiating the relationship and engagement with the researcher, direct the focus of the 
developing research and advise on the use of further research methods, depending on the researcher's sensitivity and flexibility.

(Konstantoni \& Kustatscher, 2016, p. 228)

Tickle (2017, p. 72) stresses that "the art of listening and maintaining ethical integrity" are of paramount importance to the role of an ethnographer. The outsider's demeanor of "naïve enquirer" can be informative, as the researcher negotiates the outsider/insider dialectic (Becker, 1963, as cited in Aubrey et al., 2000). The researcher(s), once having coanalyzed with participants from the early childhood care and education setting, has the responsibility of presenting the insights that have been derived from the study back to the early childhood center community and to the wider early childhood care and education sector in ways that are appropriate and meaningful. Ethically, it is a responsibility of ethnographic researchers to give back as much as they receive from the early childhood center community in which they are engaged for their project and not be perceived as taking their data and running, but maintaining the relationships long beyond the period of the study (Corsaro \& Molinari, 2000).

\section{Consideration of Issues in Ethnography in Ear- ly Childhood Education}

This final section offers discussion of a number of issues related to the conduct of ethnography in early childhood care and education. These include consideration of power dynamics and power effects in one's work as an ethnographic researcher, the issue of complexities of overlapping and fluid cultural influences, and ethical issues particular to this mode of researching.

\section{Power Dynamics and Power Effects}

Ethnography as a methodology for researching in early childhood care and education contexts offers an alternative to "traditional positivist research [that] has historically hierarchically positioned the participant as the less powerful 'other' to the researcher" (Mac Naughton, Smith, \& Davis, 2007, p. 167). Three decades on from the groundbreaking recognition of children's rights in the 1989 United Nations Convention on the Rights of the Child, policymakers, educators and researchers are still facing challenges with regard to shifting these commitments beyond rhetoric and into enactment. These challenges are complexified when researchers are working across cultures and with groups of children, their families, and communities that differ from the background of the researcher(s). Mac Naughton et al. (2007) highlight ways in which in their Australian context they have endeavored to enhance child participation in their studies as well as to acknowledge the underlying power effects in relation to the complex interreactive dynamics of adult/child/gender/ethnicity/class in their research projects. For example, they describe the tensions that arose with regard to respecting children's anxieties and preferences when invited to choose pseudonyms, an expectation that was challenged by some of 
the children. In their multi-national research on immigrant children and families in early childhood education settings in the United States and Europe led by Joe Tobin (2016), the team of co-researchers conducted approximately 150 focus groups with teachers and families to discuss the 20-minute video made in early childhood setting from that country along with two further videos from other countries. They were very conscious of the sensitivities in relation to the power dynamics with regard to the immigrant parents as well as the teachers and in particular to the vulnerability that might be felt in relation to the particular circumstances of some of the parents around language difficulties and cultural and gender issues (Jungen, Adair, Bove, \& Guénif-Souilamas, 2016). For example, facilitators struggled with their own cultural assumptions with regard to a father who spoke on behalf of his wife who remained silent, eventually recognizing the their "ethnocentric and egocentric view of the role of the women in the family and community" which had led them to seek to have the silent woman "perform their notion of self, motherhood, and citizenship [rather than] to hear her voice in her silence" (Jungen et al., 2016, p. 50).

\section{Complexities of Circles of Children's Culture Within Wider Culture(s)}

Ethnography, based as it is in the fundamental aspiration of gaining understanding of culture(s), is not a methodology suited to researchers seeking tidy and straightforward methods, analysis, and conclusions. Culture is amorphous, with children in the early childhood setting themselves reflecting the culture(s) and interests of one or more parents, grandparents, and other close family. Early childhood are and education settings reflect the culture(s) of the local communities, of the staff present, of the national curriculum and professional expectations, and to greater or lesser extents those cultures of families present. Surrounding and infiltrating these encirclements of cultures via "permeable boundaries" (Eisenhart, 2001, p. 17), is the "simultaneous existence of multiple (and sometimes competing) cultural resources in a single situation" of a particular child and family (Eisenhart, 2001, p. 21) including, increasingly, the influences of globalized popular culture. The researcher(s) is thus not merely faced with understanding the interactions and meanings within the microcosm of the early childhood setting but needs to also recognize and address the influence and interplay of the various networks of association, knowledge, and influence beyond the immediate education setting (Eisenhart, 2001). The ethnographic researcher thus needs to work closely with teachers, children, and families in the early childhood setting to gain their understandings of the meanings of important cultural symbols and the interconnections and negotiations being made by children, families, and teachers within and between the various overlapping cultural encirclements.

\section{Ethical Issues in Ethnography in Early Childhood Settings}

Ethnographic work in early childhood care and education settings, due to the extensive and intensive involvement of the researche(s)r in the setting, may involve a degree of emotional engagement that is not normally associated with the traditional role of "researcher." This may include attending funerals of family members of the early childhood community, supporting fundraising events, and being sought for advice regarding professional or even personal dilemmas faced by participants. The "personal, emotional and 


\section{Ethnography in Early Childhood Education}

identity work" (Coffey, 1999, p. 1) of conducting ethnographic fieldwork can be challenging, and thus the researcher(s) may need to ensure that they have their own professional and personal support networks in order to sustain their well-being when faced with emotionally draining situations in the research setting and to maintain the ongoing reflexivity required of this engagement. Konstantoni and Kustatscher (2016) outline some processes that assist researchers in honoring a commitment to this deep reflexivity:

In childhood ethnography, common techniques to enable a reflexive diary (in which a record is kept of thoughts, feelings, theoretical ideas, notes on how the researcher's presence might have impacted on the environment, notes of the difficulties/challenges that the researcher has faced), the use of various methods (which could assist cross-checking data or gaining further information), observing and challenging observed patterns, asking for participants' interpretations and having days away from the field.

(Konstantoni \& Kustatscher, 2016, p. 230)

An ethical issue pertaining to working with young children that may be initially insurmountable is that permission for the study to proceed is likely to have been given without consultation with the children. However, careful attention to processes of informed consent in ways that young children who are verbally capable really do understand, as well as for the parents of pre-verbal children, will go some way to remedying this oversight, and this may need to be repeated for various uses of data. This might include, for example, consulting with a child or group of children before showing a video clip of them at an academic conference. Children will need to be reminded that they have the right to opt out of data gathering such as being videoed or participating in research-related discussions (Konstantoni \& Kustatscher, 2016). Researchers also need to be sensitive to nonverbal clues that the child is uncomfortable and stop recording data as soon as this is noticed. At times children may not be able to opt out (James, 2011), such as when there is videoing taking place of a focus child but of course others are present. Technology can be applied to blur faces in this instance if selections of the video is going to be shared back to the center community for co-analyzing and accountability purposes. Particular care needs to be taken with regard to the use of these videos beyond the immediate research project. Ethical consents may have been given by the child for the immediate use of video data within the research context, but these no longer apply beyond the life of the project, and video captured for the purpose of the study should then be destroyed as per the ethical approval requirements or additional consents obtained at that later date (Konstantoni \& Kustatscher, 2016).

Another issue is the pressure that researchers may face to complete their study in a timely fashion as dictated by professional commitments. Ethnographic work takes time, first to build relationships prior to commencing the data collection, second to collect the rich, "thick," descriptive data that characterizes ethnography, and third to co-analyze this material with participants. A limitation for researchers may lie in their capacity to make sense of the situation, whether this be due to an "adultist," adult-centric interpretation of 


\section{Ethnography in Early Childhood Education}

children's actions, in which lies the potential pitfall of re-colonizing children's worlds (Cannella \& Viruru, 2004). Avoidance of this requires frank acknowledgment of adult/ child power differentials (James, 2011; Mukherji \& Albon, 2015), particularly with regard not only to the authenticity of the researcher(s) to be an adult participant observer alongside children but also to the interpretation of data and presentation of findings. There is a clear difference between "writing about and working with" (Fine \& Weiss, 1998, p. 277, as cited in Eisenhart, 2001, p. 20, emphasis in original), in relation to this ethics of representation of the data, and the potential for misrepresentation of interpretations gleaned from very young children for whom traditional means of "member-checking" may not be possible. This requires a deep sensitivity and commitment to ongoing self-reflexivity on the part of researchers (Tickle, 2017), along with a profound respect for children's agency both in determining their own "enculturation" and as research participants.

A further ethical consideration for ethnographic research in early childhood education is that in the presentation of the very rich detailed data that have been gathered there is a potential for identifiability of both individuals and the early childhood setting, and considerable care needs to be taken to avoid this unless there is a pre-existing understanding that all involved are willing for theirs and the identity of their early childhood care and education center to be made known. Given the possibly daunting broad range and depth of data gathered (Mukherji \& Albon, 2015), and the necessity for selectivity of presentation of various aspects of the data, attention needs to be paid to the possibility that certain voices could be privileged over others (Eisenhart, 2001). Furthermore, ethnographic data is often "messy," involving ethical tensions, contrasting voices, and contradictory meanings (Konstantoni \& Kustatscher, 2016), which can be challenging to researchers who in seeking to generate strong coherent narratives within their study may "overlook or ignore contested, ambiguous or inconsistent data" (Eisenhart, 2001, p. 23).

A final issue to be noted is that the majority of ethnographic studies in early childhood care and education settings have been conducted in the Global North, which may be due to the predominance of early childhood education institutions in these countries and the lesser reliance on these in the Global South (Konstantoni \& Kustatscher, 2016). Konstantoni and Kustatscher point out that the production of research from predominantly Western contexts raises issues in terms of the underrepresentation of young children in families and societies that do not use formal early childhood care and education settings. Other questions could be asked about the representation of diverse ethnic groups in research conducted in settings dominated by the majority culture. "Thus, reflecting on which young children are included in ethnographic research, and which are not, puts questions about marginality and the production of knowledge more generally on the agenda" (Konstantoni \& Kustatscher, 2016, p. 233).

Despite the plethora of research that points to the benefits of participation in high-quality, culturally responsive early childhood education, the ongoing marginalization by governments of early childhood care and education, positioning this outside of the compulsory education sector, means that more research is required to demonstrate the components of early childhood care and education practices that are of the greatest benefit for 
young children and their families. Ethnography in early childhood education has the potential to provide this detail via the researchers' "reflexive attention to relational aspects" (Konstantoni \& Kustatscher, 2016, p. 234).

\section{Conclusion}

Ethnography, when done well, is time-consuming, emotionally draining, messy, fraught with ethical dilemmas, and involves deep commitment to participants beyond the realm of the research itself. Yet ethnographic methodologies offer pathways toward greater awareness of and insights into the lives of people in the communities of focus and are particularly valuable in sharing understandings of communities whose lives are less well supported by dominant societies. Cycles of educational failure are perpetuated when policymakers lack or fail to attend to nuanced understandings of the impacts of complex historical, economic, political, cultural, and social factors on different communities subsumed within a dominant culture. Children, along with Indigenous peoples, have faced particular challenges in not being heard while surviving under regimes of colonization, the impacts of which continue to perpetuate cycles of disadvantage (Cannella \& Viruru, 2004; Smith, 1995, 1999/2012). Meanwhile, children in countries in the Global South face increasing challenges such as the impacts of intensifying climate change (Burton, Mustelin, \& Urich, 2011; Lawler, 2011). As Pence and Nsamenang (2008) write, "At the heart of our concern is that the polyphonic diversity of childhood globally is not being heard, and that homogenising forces are increasing in strength and reach" (p. 2). Ethnography in early childhood education is not just "a way of looking and a way of seeing" (Wolcott, 2008, p. 41 ), it is also a way of listening and a way of hearing, since it provides a means of giving voice to the concerns of young children, their families, communities, and teachers in diverse settings.

\section{Bibliography}

Aubrey, C., David, T., Godfrey, R., \& Thompson, L. (2000). Early childhood educational research. Issues in methodology and ethics. London: Routledge/Falmer Press.

Cannella, G. S., \& Viruru, R. (2004). Childhood and postcolonization. Power, education and contemporary practice. New York: RoutledgeFalmer.

Corsaro, W. A. (1985). Friendship and peer culture in the early years. Norwood, NJ: Ablex.

Corsaro, W. A. (1996). Transitions in early childhood: The promise of, comparative, longitudinal ethnography. In R. Jessor, A. Colby, \& R. A. Shweder (Eds.), Ethnography and human development. Context and meaning in social inquiry (pp. 419-458). Chicago: University of Chicago Press.

Corsaro, W. A. (2003). "We're friends, right?": Inside kids' cultures. Washington, DC: Joseph Henry Press. 
Corsaro, W. A., \& Molinari, L. (2000). Entering and observing in children's worlds: A reflection on a longitudinal ethnography of early education in Italy. In P. Christensen \& A. James (Eds.), Research with children. Perspectives and practices (pp. 179-200). London: Falmer Press.

Eisenhart, M. (2001). Educational ethnography past, present, and future: Ideas to think with. Educational Researcher, 30(8), 16-27.

James, A. (2011). Ethnography in the study of children and childhood. In P. Atkinson, A. Coffey, S. Delamont, J. Lofland, \& L. Lofland (Eds.), Handbook of ethnography (pp. 122). London: SAGE.

Konstantoni, K., \& Kustatscher, M. (2016). Conducting ethnographic research in early childhood research: Questions of participation. In A. Farrell, S. L. Kagan, \& E. K. M. Tisdall (Eds.), The SAGE handbook of early childhood research (pp. 223-239). Los Angeles: SAGE.

Lubeck, S. (1985). Sandbox society: Early education in black and white America-A comparative ethnography. London: Falmer Press.

Mac Naughton, G., Smith, K., \& Davis, K. (2007). Researching with children. The challenges and possibilities for building "child friendly" research. In A. J. Hatch (Ed.), Early childhood qualitative research (pp. 167-184). New York: Routledge.

Mukherji, P., \& Albon, D. (2015). Ethnography. Research methods in early childhood. An introductory guide (2nd ed., pp. 85-100). Los Angeles: SAGE.

Polakow Suransky, V. (1982). The erosion of childhood. Chicago: University of Chicago Press.

Siraj-Blatchford, I., \& Siraj-Blatchford, J. (2001). An ethnographic approach to researching young children's learning. In G. Mac Naughton, S. A. Rolfe, \& I. Siraj-Blatchford (Eds.), Doing early childhood research. International perspectives on theory and practice (pp. 193-207). Crows Nest, Australia: Allen \& Unwin.

Tobin, J. (Ed.) (2016). Preschool and im/migrants in five countries. Brussels: Peter Lang.

Tobin, J., Arzubiaga, A., \& Adair, J. K. (2013). Children crossing borders. Immigrant parent and teacher perspectives on preschool. New York: Russell Sage Foundation.

Tobin, J., Hsueh, Y., \& Karasawa, M. (2009). Preschool in three cultures revisited. China, Japan and the United States. Chicago: University of Chicago Press.

Tobin, J., Wu, D. Y., \& Davidson, D. H. (1989). Preschool in three cultures: Japan, China, USA. New Haven, CT: Yale University Press. 


\section{References}

Adair, J. (2011). Advocating for ethnographic work in early childhood federal policy: Problems and possibilities. Anthropology \& Education Quarterly, 42(4), 422-433.

Aubrey, C., David, T., Godfrey, R., \& Thompson, L. (2000). Early childhood educational research. Issues in methodology and ethics. London: Routledge/Falmer Press.

Becker, F. (1963). Outsiders. New York: The Free Press.

Benedict, R. (1983). Race and racism. Henley, U.K.: Routledge \& Kegan Paul.

Burton, D., Mustelin, J., \& Urich, P. (2011). Climate change impacts on children in the Pacific: Kiribati and Vanuatu. Bangkok: UNICEF.

Cannella, G. S., \& Viruru, R. (2004). Childhood and postcolonization. Power, education and contemporary practice. New York: RoutledgeFalmer.

Coffey, A. (1999). The ethnographic self: Fieldwork and the representation of identity. London: SAGE.

Corsaro, W. A. (1985). Friendship and peer culture in the early years. Norwood, NJ: Ablex.

Corsaro, W. A. (1996). Transitions in early childhood: The promise of, comparative, longitudinal ethnography. In R. Jessor, A. Colby, \& R. A. Shweder (Eds.), Ethnography and human developement. Context and meaning in social inquiry (pp. 419-458). Chicago: University of Chicago Press.

Corsaro, W. A. (2003). "We're friends, right?": Inside kids' cultures. Washington, DC: Joseph Henry Press.

Corsaro, W. A. (2015). The sociology of childhood (5th ed.). Thousand Oaks, CA: SAGE.

Corsaro, W. A., \& Molinari, L. (2000). Entering and observing in children's worlds: A reflection on a longitudinal ethnography of early education in Italy. In P. Christensen \& A. James (Eds.), Research with children. Perspectives and practices (pp. 179-200). London: Falmer Press.

Eder, D., \& Corsaro, W. (1999). Ethnographic studies of children and youth. Theoretical and ethical issues. Journal of Contemporary Ethnography, 28(5), 520-531.

Eisenhart, M. (2001). Educational ethnography past, present, and future: Ideas to think with. Educational Researcher, 30(8), 16-27.

Erickson, F. (2011). A history of qualitative inquiry in social and educational research. In N. K. Denzin \& Y. S. Lincoln (Eds.), The SAGE handbook of qualitative research (4th ed., pp. 43-59). Thousand Oaks, CA: SAGE. 
Fernie, D. E, Davies, B., Kantor, R., \& McMurray, P. (1993). Becoming a person in the preschool: Creating integrated gender, school culture, and peer culture positionings. Qualitative Studies in Education, 6(2), 95-110.

Fine, M., \& Weis, L. (1998). The unknown city. Boston: Beacon Press.

Geertz, C. (1973). The Interpretation of Cultures. New York: Basic Books.

Hardman, C. (1973/2001). Can there be an anthropology of children?Childhood, 8(4), 501-517.

Hayashi, A., \& Tobin, J. (2015). Teaching embodied: Cultural practices in Japanese preschools. Chicago: University of Chicago Press.

James, A. (2011). Ethnography in the study of children and childhood. In P. Atkinson, A. Coffey, S. Delamont, J. Lofland, \& L. Lofland (Eds.), Handbook of ethnography (pp. 122). London: SAGE.

Jungen, A., Adair, J., Bove, C., \& Guénif-Souilamas, N. (2016). Focus groups. In J. Tobin (Ed.), Preschool im/migrants in five countries. England, France, Germany, Italy and the United States of America (pp. 39-51). Brussels: Peter Lang.

Kincheloe, J. L., McLaren, P., \& Steinberg, S. R. (2012). Critical pedagogy and qualitative research: Moving to the bricolage. In S. R. Steinberg \& G. S. Cannella (Eds.), Critical qualitative research reader (pp. 14-32). New York: Peter Lang.

Konstantoni, K., \& Kustatscher, M. (2016). Conducting ethnographic research in early childhood research: Questions of participation. In A. Farrell, S. L. Kagan, \& E. K. M. Tisdall (Eds.), The SAGE handbook of early childhood research (pp. 223-239). Los Angeles: SAGE.

Lawler, J. (2011). Children and climate change. Children's vulnerability to climate change and disaster impacts in East Asia and the Pacific. Bangkok: UNICEF East Asia and Pacific Regional Office.

LeVine, R. A. (2007). Ethnographic studies of childhood: A historical overview. American Anthropologist, 109(2), 247-260.

Lubeck, S. (1985). Sandbox society: Early education in black and white America-A comparative ethnography. London: Falmer Press.

Mac Naughton, G. (1993). Gender, power and racism: A case study of domestic play in early childhood. Multicultural Teaching, 11(3), 12-15.

Mac Naughton, G., Smith, K., \& Davis, K. (2007). Researching with children. The challenges and possibilities for building "child friendly" research. In A. J. Hatch (Ed.), Early childhood qualitative research (pp. 167-184). New York: Routledge.

Mead, M. (1928). Coming of age in Samoa. Harmondsworth, U.K.: Penguin. 
Mead, M. (1942). Growing up in New Guinea: A study of adolescence and sex in primitive societies. Harmondsworth, U.K.: Penguin.

Mukherji, P., \& Albon, D. (2015). Ethnography. In Research methods in early childhood. An introductory guide (2nd ed., pp. 85-100). Los Angeles, CA: SAGE.

Pence, A., \& Nsamenang, B. (2008). A case for early childhood development in sub-

Saharan Africa. The Hague, Netherlands: Bernard Van Leer Foundation.

Polakow Suransky, V. (1982). The erosion of childhood. Chicago: University of Chicago Press.

Rossholt, N. (2009). The complexity of bodily events through an ethnographer's gaze: Focusing on the youngest children in preschool. Contemporary Issues in Early Childhood, 10(1), 55-65.

Siraj-Blatchford, I., \& Siraj-Blatchford, J. (2001). An ethnographic approach to researching young children's learning. In G. Mac Naughton, S. A. Rolfe, \& I. Siraj-Blatchford (Eds.), Doing early childhood research. International perspectives on theory and practice (pp. 193-207). Crows Nest, Australia: Allen \& Unwin.

Smith, L. T. (1995). The colonisation of Māori children. Youth Law Review (August/ September/October), 8-11.

Smith, L. T. (1999/2012). Decolonizing methodologies. Research and indigenous peoples. London: Zed Books.

Taylor, A., \& Pacini-Ketchabaw, V. (2015). Learning with children, ants, and worms in the Anthropocene: Towards a common world pedagogy of multispecies vulnerability. Pedagogy, Culture \& Society, 23(4), 507-529.

Tickle, S. (2017). Ethnographic research with young people: methods and rapport. Qualitative Research Journal, 17(2), 66-76.

Tobin, J. (Ed.) (2016). Preschool and im/migrants in five countries. Brussels: Peter Lang.

Tobin, J., Arzubiaga, A., \& Adair, J. K. (2013). Children crossing borders. Immigrant parent and teacher perspectives on preschool. New York: Russell Sage Foundation.

Tobin, J., \& Hayashi, A. (2017). Return interviews and long engagements with ethnographic informants. Anthropology \& Education Quarterly, 48(3), 318-327.

Tobin, J., Hsueh, Y., \& Karasawa, M. (2009). Preschool in three cultures revisited. China, Japan and the United States. Chicago: University of Chicago Press.

Tobin, J., Wu, D. Y., \& Davidson, D. H. (1989). Preschool in three cultures: Japan, China, USA. New Haven, CT: Yale University Press. 
Warming, H. (2011). Getting under their skins? Accessing young children's perspectives through ethnographic fieldwork. Childhood, 18(1), 39-53.

Wolcott, H. F. (2008). Ethnography. A way of seeing (2nd ed.). Lanham, MD: Altamira.

Zimmer, R. (1979). Necessary directions for anthropological research on child care in the United States. Anthropology \& Education Quarterly, 10(3), 139-165.

\section{Jenny Ritchie}

Victoria University of Wellington 